\title{
BETWEEN CRAFT AND REGULATIONS
}

\author{
Experiences with the Construction of Two "Super insulated" Buildings in Norway
}

by Ruth Woods \& Marius Korsnes

The Norwegian government uses building regulations to influence the construction industry, and they directly affect how craftspeople from the industry apply their skills. In this paper, we investigate the negotiations between the meaning and value associated with the requirements for the material structure and the craftsperson\&\#39;s role. Two houses in Central Norway are the starting point, where qualitative methods, primarily semi-structured interviews and observation, are used to gain insight into the craftsperson's view of the building regulations. The houses represent two different building standards. A Passive House in Åfjord Municipality, completed in 2014, and ZEB Living Lab in Trondheim, a zero emission building (ZEB), completed in 2015. In Norway, the building regulations are reviewed every five years. In 2011, craftspeople were constructing buildings to the low-energy standard. This led to an increased focus on "super insulating" building techniques during the period 2013-16 when the case studies took place. Starting with a craftsperson\&\#39; view, this paper asks what implications the increasing demands for energy efficient and environmentally friendly buildings have on the role of the craftsperson and their application of skill. The construction industry bases much of its activity on Norwegian construction traditions and skill; and this guides the development of new generations of buildings. The paper shows that the use of established skills and knowledge is both a strength and a challenge when dealing with a new set of building regulations. Skill is a resource to build upon, but it is also influenced by a conservativism that has difficulties getting beyond the extra time and costs associated with new regulations. It can therefore function as a barrier to the use of construction crafts to establish more sustainable building forms within the Norwegian market.

Keywords: Authors: 


\section{$\$$}

NORDIC JOURNAL

of Science and Technology Studies

\section{Introduction}

The EU roadmap from 2011 proposes that the better construction and use of buildings could influence $42 \%$ of final energy consumption, about $35 \%$ of our greenhouse gas emissions and more than $50 \%$ of all extracted materials (EU Roadmap 2017 [r]). The same roadmap proposes that by 2020 all new buildings should be nearly zero-energy and highly material efficient. In Norway, this ambition has been manifested through a 2012 White Paper stating that building regulations should reach nearly zero energy by 2020. The Norwegian white paper "Good buildings for a better society" indicated that all new houses should fulfil Passive House level from 2015 (Ministry of Local Government and Regional Development 2012). During the past five years the introduction of Passive House and zero emission buildings (ZEB) in Norway has escalated, and this has impacted on engineers, designers, architects, craftspeople, and the people inhabiting these buildings. The EU Roadmap and Norwegian building regulations from 2011 have led to the development of building concepts that are "super-insulated", reducing space-heating requirements (Georges et al. 2017:7[r]). Users have been known to call these super-insulated buildings "plastic bag" houses-saying something about the controversy associated with these very airtight and highly insulated buildings'. Two "super-insulated" buildings in Central Norway provide insight into the production of meaning surrounding the role of craftspeople when building energy and material efficient houses. The buildings allow a consideration of the construction process, their material form and the interpretation of the building regulations. If we are to live less energy and $\mathrm{CO}_{2}$ intense lives in the future, then how we build is expected to change. Understanding how craftspeople are involved in the construction of low-carbon and energy houses will provide useful knowledge when crafting future sustainable buildings. The intention here is to describe the changing role-if any-of craftspeople in Norway based on the craftsperson's response to the process of constructing two sustainable buildings. Thus, this analysis increases our knowledge about the way in which climate knowledge is negotiated, as it is manifested in new building regulations and how it aligns with craftspeople' s experiential knowledge.

Central within this analysis are the Norwegian building regulations and standards, and how the implementation of technical requirements found within the standards influences the construction process and a craftsperson's use of skills and knowledge. Building regulations change, within the period described in this paper, 2013 - 2016, a new standard, the Norwegian Passive House standard was increasingly taken into use, and a new set of building regulations was under development, what eventually became TEK $17^{2}$. The Norwegian government uses the building regulations as guidelines for the construction industry3. The regulations establish the minimum of technical requirements necessary in order for a building to be lawfully registered as a building. They may, however, also be understood as the maximum requirements and as such may not necessarily function as incentives for the construction of buildings that are more energy efficient (Ryghaug and Sørenson 2009:987 $\left.7^{[\mathrm{r}}\right)$. In an analysis of why the building industry has failed to build more energy efficient in Norway, Ryghaug and Sørensen $\left(2009^{[i]}\right)$ suggest three main reasons: deficiencies in public policy, limitations in governmental regulations and a general conservatism in the building industry (Ibid.: 984). This combination hints at the challenges faced by craftspeople.

The construction industry is under pressure to build more sustainably. The understanding of sustainability used here focuses particularly on buildings, and suggests limiting the negative environmental impact of buildings through how materials, energy and space are used. Based on a survey of sustainable building definitions, Berardi (2013 $\left.3^{(r)}\right)$ suggests that a sustainable building can be defined as "a healthy facility designed and built in a cradle-tograve resource-efficient manner, using ecological principles, social equity, and life-cycle quality value, and which promotes a sense of sustainable community" (Berardi 2013:76[r). Sustainability is therefore not just about reducing energy consumption; it also affects the materials included, the construction process itself and the way the building is used.

The demand for greater sustainability in buildings is influencing building regulations. Since the 1990's the Norwegian regulations have been revised approximately every five years. In 2011, the Norwegian Directorate for Building Quality (DiBK) stated that the Norwegian building stock "accounts for about $40 \%$ of domestic energy consumption in Norway. The building industry is therefore an important player in the effort to reduce the country's overall environmental impact from energy use." (DiBK 2017[ ${ }^{[\mathrm{r})}$ ). Achieving greater sustainability in buildings has often meant reducing energy use, particularly space heating and this has caused the emergence of building concepts that are based on super-insulated walls, floors and roofs, such as the Passive House standard (Georges et al. 2017: $7^{[1]}$ ).

In 2011, the regulations supported the construction of "Low-Energy Housing", but the next set of regulations was already under discussion and the Passive House standard was expected to be part of the forthcoming regulations. Norway introduced its own Passive House standards for residential buildings and non-residential buildings (NS 3700) (NS 3701) in 2010 and 2012. A Passive House requires approximately $25 \%$ of the heating necessary for a house built according to the previous Norwegian regulations (Standard Norge, $\left.2010^{[[l]}\right)$. In order to achieve low energy-use the building envelope

1 https://brage.bibsys.no/xmlui/bitstream/handle/11250/2455760/masteroppgavelinelyngstad.pdf?sequence=1\&isAllowed=y

2 TEK15 was planned but it was not approved until 2017 and the final version of the building regulations thereby became TEK17 https://dibk.no/byggereglene/byggteknisk-forskrift-tek17/. 3 https://dibk.no/byggregler/tek/ 


\section{$\$$}

NORDIC JOURNAL

of Science and Technology Studies

is more insulated and windows are triple-glazed. The Norwegian Passive House standard NS 3700 also includes airtightness requirements. The regulations aim to ensure that the measures that are planned and implemented take into consideration good visual quality, universal design and meet technical requirements for safety, environment, health and energy ( $\left.\mathrm{DiBK} 2017^{[\mathrm{rl}}\right)$. Amendments were made to the regulations in 2016, changes include, increased energy requirements, stricter demands for energy components and fossil fuel heating is no longer permitted. The construction industry is currently interpreting the amended regulations in practical terms. The Norwegian Low-Energy program, which disseminates energy effective solutions for buildings to the construction industry, states that "In practice, the new energy requirements mean better windows (U-value o.8), better density (leakage number 0.6 ), better insulated floors, a larger window area, and reduced thermal-bridge values"4. Concepts for the Norwegian Zero Emission buildings (ZEB's) are also based on super-insulation.

The paper is structured as follows: Section 2 presents the meaning and value associated with craft, and discusses the craftsperson's relationship with the building regulations. Section 3 describes the two houses and the social and technical systems around them and then presents the methodology used. Section 4 presents some of the narratives associated with the two houses. The Passive House in Åford is presented first and ZEB Living Lab completes the section. Section 5 provides a discussion and some concluding analysis.

\section{Crafts, Meaning and Sustainable Buildings}

This paper centres on the relationship between concepts and things (Henare et al. 2007:2[ $2^{[r]}$ ). It is suggested here that there is a close association between the process of constructing a building and the meanings associated with the same building. The interaction between the craftsperson, the building and the building regulations are considered, because it is not simply the material context that is affected by changes in the requirements for buildings. They also have an impact on how a craftsperson applies their skill, the meaning and value surrounding a building and its use, and the expected sustainability-outcomes.

Craft is easily associated with tradition, weaving, pottery, stone masonry and the fine arts of painting and sculpture, but if we look at the actions that define a craftsperson, the term may be associated with a much wider variety of activities. Craft, according to Sennett $\left(2008^{[r}\right)$, is not associated with particular fields, methods or tools used; it is about the attitude to the work. Craftspeople who are "dedicated to good work for its own sake" represent "the special human condition of being engaged" and take "pride in their work" (Sennett 2008:20[r). We recognised this attitude or work ethic among craftspeople from the construction industry and those who were involved in constructing the two houses presented here.

A work ethic requires an activity and in the craftsperson's case, the starting point is skill. Skill is routine and experienced practice, which contrasts with sudden inspiration (Sennett 2008:37[ $)$. Learning a skill requires repetition, but once a skill is in place it offers control over materials and tools. The craftsperson follows the materials and task "while bending it to their evolving purpose" (Ingold 2009:92 $2^{[\mathrm{I}}$ ). Skill is social and it connects to predecessors and to our fellows (ibid.: 22). Skills are passed from craftsperson to craftsperson, but this does not mean they are rigid. A craftsperson interprets drawings and finds solutions based on knowledge, materials and skill that may be outside the expectations of what is planned. In the construction industry, a craftsperson is working with materials that may not willingly fit into the required forms, or remain in them (ibid.: 93). A carpenter follows the materials, the way they change due to wear and tear, and as their form changes, for example, from wooden planks to the surface of a floor. This experienced knowledge exists in parallel and sometimes in contrast to requirements put down in novel building regulations and will be explored in more detail here.

The construction industry is in general described as a fragmented, but complex social context, which is in large part due to the numerous small to medium sized actors which are part of the industry (Van Bueren and De Jong 2007:554 $\left.4^{[\mathrm{r}}\right)$. Some recent research focuses on craftspeople who are part of the social context within low carbon construction, e.g. focusing on the role of retrofit advisers (Owens et al. $2014^{[r]}$ ), middle actors or building professionals (Parag and Janda 2014 $4^{[i]}$ ) and heating engineers (Wade et al. 2016 [i]). In the face of increasing attention to reducing energy use in buildings and increasing the sustainability of the building stock, this research is in general is pertinent. Nevertheless, as pointed out by Wade et al. (2016:40[r]) 'building professionals and practitioners remain under-investigated in energy and building research'. In Norway too, research has been scarce on the role of craftspeople during the construction of sustainable buildings, or on how their use and interpretation of the building regulations influence this process. This in despite small and medium sized companies also dominating the Norwegian industry (Ryghaug and Sørensen 2009:988 $\left.8^{[]}\right)$. A more common strategy, both in and outside Norway, has been to consider the actions of those designing and developing buildings, the architects and engineers (Gunn 2006[r], Andresen and Hegli, $2016^{[r]}$, and Stender $2017^{[r]}$. It is suggested here that greater focus on the craftsperson, someone often working in smaller construction companies, may provide the background to understand and deal with the conservatism mentioned in the introduction.

In a qualitative analysis of the energy efficient renovation of singlefamily homes, Risholt and Berker (2013 $\left.3^{[i]}\right)$ stated that the craftsperson in their role as an expert during the renovation process

4 http://lavenergiprogrammet.no/artikkel/nye-energikrav-i-byggteknisk-forskrift/ 
might actually be a barrier to achieving a more energy efficient dwelling. This could be related to limited knowledge about innovative products and a focus on cost (Risholt and Berker 2013:1028 (r) ). Ryghaug and Sørensen (2009:988 $8^{[r]}$, state that innovation within the construction industry is limited and propose that greater focus on innovation, through research and design, will support efforts to improve energy efficiency in buildings, but that the building industry scores low on research investment. This seems partially due to the majority of companies within the construction industry being small to medium sized. Van Bueren and De Jong (2007[r) propose a "continued coupling between research and practice" as a solution to the distance between policy and the construction industry. The use of pilot projects to encourage dissemination is another solution to the lack of interest in research investment. Presenting real-life examples in the form of pilot buildings that are developed, tested and used by different actors, craftspeople and others, from the construction industry (Gustavsen 2017 $7^{[[]}$, Andresen 2017[r] ${ }^{5}$.

The meaning surrounding the role of craftspeople in the construction industry is closely associated with the buildings that they construct. The insides and outsides of buildings are various, differentiated spaces allotted to different intentions. The construction of a building is part of the meaningful complex, adding to or replacing existing understandings about what buildings do and how they may be used. The building of a house, a school or an office building, is intentional action that is future orientated (Gell $\left.1998: 256^{[[]}\right)$. How we build and what we build can affect the way we live. For example, the way the Passive Houses are heated and ventilated. However, the built form is not necessarily understood in a single way, there exist differing attachments or commitments to what initially appear to be the same mutually intelligible phenomenon (Buchli 2013:16[r]). Building regulations, Passive House and zero emission definitions offer further variations to our understandings about buildings, and have the potential to play many different roles in social life (Miller 1983:201[r]). These are converging with understandings about sustainability, reduced energy and material use, as well as demands for increased comfort levels that are circulating in society. In this paper, we want to investigate further, how craftspeople experience these negotiations. Thus, we discuss negotiations between the meaning and value associated with the requirements for the material structure and the craftsperson's role.

\section{Overview of the two cases and methodology}

Having introduced the theoretical underpinnings of this paper, we now briefly introduce the two cases, the Passive House in Åfjord and ZEB Living Lab, and our research methods. The two projects took place independently of each other, but are considered together because they both look closely at the activities of craftspeople within the construction industry in Norway. The data collection for Åford took place in 2012-2013 and in ZEB Living Lab in 2015. Both cases in this paper are pilot projects and are intended to function as inspiration for craftspeople and homeowners, and by 'dazzling' the beholder (Gell 1998:44[ ${ }^{[r]}$ ) showcasing a realised manifestation of a the 'future home'.

Living Lab and the Åfjord Passive House have both been used to gather and disseminate knowledge to craftspeople from the construction industry. The two pilot buildings are otherwise different in concept, scope and aims. The ZEB Living Lab is used to gather new knowledge about zero emission buildings and aims to support the establishment of zero emission buildings as a viable concept, nationally and internationally. The Åfjord project primarily aimed at communicating existing knowledge about Passive Housing and developing an educational program that would disseminate knowledge in local communities in Central Norway ${ }^{6}$.

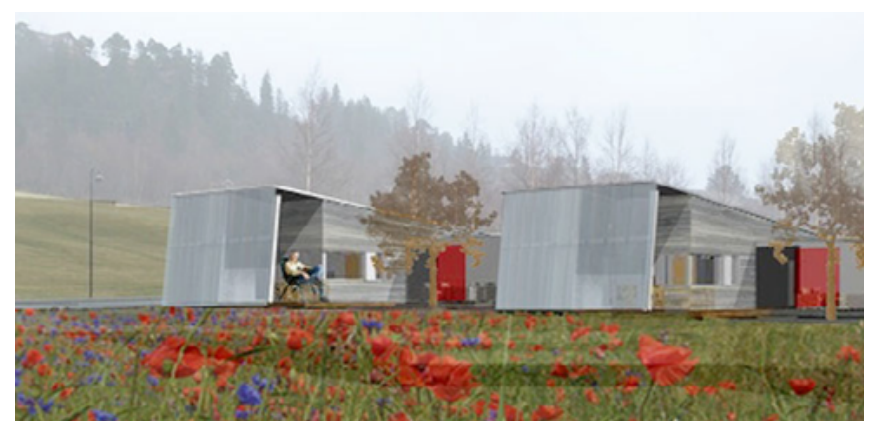

Figure 1: Passive houses at Vassneset in Åfjord Municipality. (Eggen Architects 2012)

The Åfjord project aimed to provide both reasonably priced social housing for the municipality and a practice-based program to teach high school pupils the skills necessary to build Passive Houses?. The course program developed followed the same progression as the construction process. The house was located in Åford on the Vassneset site and was built for multi-handicapped members of the community. It is single story, universally designed, with a floor area of approximately 70 square meters, which includes the space for the storage of wheelchairs and other specialised equipment ${ }^{8}$

\footnotetext{
5 The case studies in this paper are pilot buildings. See description from page 5

6 The Norwegian Housing Bank coordinated collaboration between Åford High School, the Program for Construction Education, and SINTEF Building and Infrastructure. The pilot building in Åfjord inspired four other building and education projects in different municipalities within central Norway (Woods et al. 2013b: 10).

7 The Norwegian high school is three-year period of education normally starting when the pupil is sixteen and is completed at the age of nineteen.

8 The houses in Åford were finished after the research project was completed, and no residents were interviewed.
} 


\section{$\mathbb{N}$}

NORDIC JOURNAL

of Science and Technology Studies

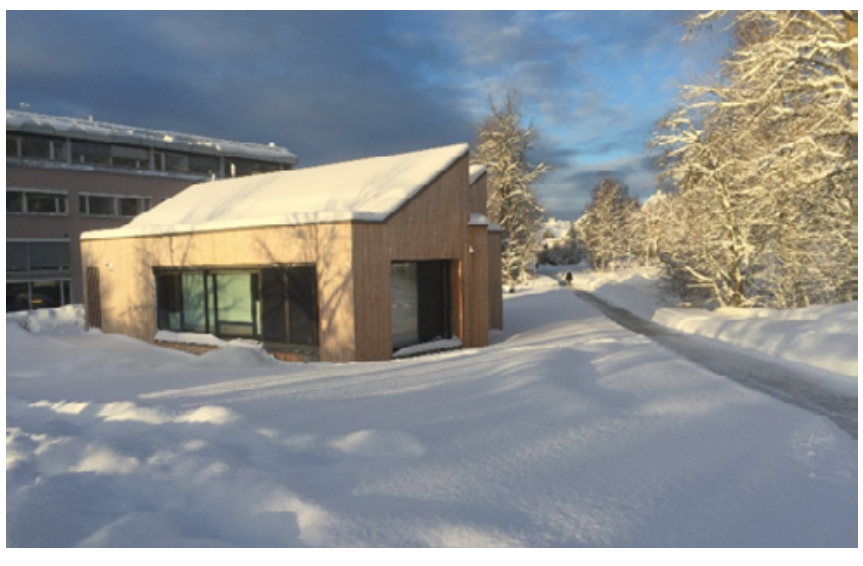

Figure 2: ZEB Living Lab, January 2016 (architect, Luca Finocchiaro)

Zero-emission buildings (ZEB) suggests the next stage in the building regulations after Passive Houses. A ZEB requires less energy for heating than a regular building because, in a similar way to a Passive House, the building envelope is more insulated and the ventilation system more effective for heat recovery. In addition, the house is able to supply its own energy needs and the building materials, preferably have, low carbon emissions. The ZEB concept aims to achieve a minimum of $\mathrm{CO}_{2}$ production through energy and materials used. ZEB Living Lab is a single-family house with a heated floor area of approximately 102 square meters ${ }^{9}$. The house integrates state-of-the-art technologies for building envelopes, building equipment, solar energy exploitation, heating and ventilation systems, and control interfaces ${ }^{10}$.

The two pilot projects aim to extend the knowledge within the construction industry by reaching out to craftspeople directly through dissemination processes and, in the case of the ZEB pilot, by attempting to influence building standards. At the time of their construction both houses were at the forefront of building regulations and the challenges met by the craftspeople working on their construction highlight the changes affecting craftspeople in general. A ZEB is in many ways a Passive House that has added a renewable energy source allowing it to supply its own energy needs. Building upon Passive House technology ZEBs suggest the future of sustainable housing. Living Lab therefore provides insight into what has happened to Passive House knowledge, and the expectations about future building regulations.

\section{Data collection and analysis}

An anthropological approach relevant to meeting craft in the field is one that through participating in routine activities bridges the distance between experience and analysis, simplifying the encounter with a multitude of meanings connected with the construction process (Henare et al. 2007:4[1]). This suggests an ideal, but participating in routine activities is not always possible and this was the case when following the building process connected to the two houses presented here. Methods have been used which offer routes into understanding people's lives, experiences and values, but which are not necessarily associated with the classic observational approach (Pink 2009:9[i]). This paper is based on three main types of data: Observation, semi-structured interviews (face-toface and telephone) and a focus group interview. Observation took place in the context of different social fora organised around the construction of the two buildings. We followed the construction process and gathered stories about the buildings from craftspeople and people associated with the design and use of the two houses. Observation provided opportunities to follow and understand the construction processes taking place. The opportunities for observation were part of the practical and social context, and provided the research team with the background to understand the interview data presented in the paper.

In Åfjord observation took place within the framework of a series of classroom presentations and site visits which normally lasted the length of a school day. These often had a workshop format and followed a linear process where teachers and pupils received information about Passive House construction and were given practical or theoretical problems to solve or discuss. In ZEB Living Lab, the fora for observation were mostly shorter (hour-long meetings) or short informal site visits (during the construction process). Site visits depended on the activities taking place in the building. It was important not to disturb the craftspeople at work or hinder their progress. The length of the interviews in both projects varied depending on the informant. The shortest interviews were with the pupils from Åfjord High School and lasted thirty minutes. The longest interviews were with craftspeople from Living Lab and lasted almost two hours. The time and place for the interviews and themes to be covered by the interview were agreed upon prior to the interview. The interviews and other fora are presented in tables 1 and 2 .

The craftspeople from the two cases presented here, are mostly men. There are women working in the Norwegian construction industry. In 2017 of the total working in the construction industry $22 \%$ were women". Only one of the craftspeople working on the two houses were women. It should also be noted that the term in Norwegian is gender-neutral as it (håndverker) refers to a manual worker, i.e. using his/her hands. All the craftspeople who took part in the Åfjord and ZEB Living Lab projects are anonymous, when presenting their narratives or comments, and to be able to present them individually, we have given each of the craftspeople referred directly to, in the paper a pseudonym ${ }^{12}$. The majority of informants from both

\footnotetext{
9 ZEB Living Lab is a residential research laboratory where user behaviour may be studied in interaction with zero emission technology. Six groups of people lived in ZEB Living Lab, from October 2015 to April 2016 (Korsnes 2017; Korsnes et al. 2017).

10 For a more technical description of ZEB Living Lab see Goia et al. (2015).

11 https://www.ssb.no/befolkning/nokkeltall/likestilling 29.05.2017

12 Both projects were reported to the Norwegian Centre for Research Data, which specifies rules for anonymity and data storage http://www.nsd.uib.no/nsd/english/index.html
} 
case studies were experienced craftspeople, who had worked in the construction industry for a number of years. Exceptions to this rule are the two school pupils who were interviewed in Åford and who began their apprenticeships during the autumn in 2013. In ZEB Living Lab, most of the automated engineer's experience was within a laboratory context. He had no experience of building automation within houses or offices outside the university campus.

\section{TABLE 1}

\begin{tabular}{|c|c|c|c|}
\hline$\#$ & $\begin{array}{l}\text { Informant/ } \\
\text { interviewee }\end{array}$ & $\begin{array}{l}\text { Number } \\
\text { of people }\end{array}$ & $\begin{array}{l}\text { Type } \\
\text { of data }\end{array}$ \\
\hline 1 & Teacher & 1 & One semi-structured interview \\
\hline 2 & $\begin{array}{l}\text { Teacher and } \\
\text { carpenter (Jan) }\end{array}$ & 1 & $\begin{array}{l}\text { Two semi-structured } \\
\text { interviews. One in } 2013 \text { and } \\
\text { one over the telephone in } 2017\end{array}$ \\
\hline 3 & Pupil (Martin) & 1 & One semi-structured interview \\
\hline 4 & Pupil (Kristin) & 1 & One semi-structured interview \\
\hline 5 & $\begin{array}{l}\text { A project manager } \\
\text { and a carpenter }\end{array}$ & 2 & $\begin{array}{l}\text { Observed discussion at } \\
\text { a construction site }\end{array}$ \\
\hline 6 & $\begin{array}{l}\text { Pupils, teachers } \\
\text { and craftspeople }\end{array}$ & 30 & $\begin{array}{l}\text { Five organised workshops } \\
\text { at construction site } \\
\text { with observation }\end{array}$ \\
\hline
\end{tabular}

Table 1: Overview of data collection in Åjord Passive House

The Passive House course in 2012 and 2013 in Åfjord Municipality provided opportunities to interact with experienced craftspeople (teachers and members of the local construction industry in, and around Åford, during on site meetings and in classroom situations) and high school pupils who had not yet begun their careers'3. In addition, we interviewed two pupils and two members of the teaching staff at Åfjord High School. As part of the coursework, pupils and teachers went on a fieldtrip where they visited the building site for what was then Scandinavia's largest Passive House estate. The dialogue between researchers, pupils, the housing estate's project manager and one of the three craftspeople working on the site, who guided us around the building site, is also part of the dataset. The Åfjord project took place when Passive House was expected to become the new housing standard, but before the current 2017 regulations came into effect. At that time there were still relatively few Passive Houses built and in use. The data collection in 2012-13 emphasised the pupil's learning process, the building regulations themselves were not the focus of the project. The Åfjord case provides background to understand changes that were taking place to the building regulations and how these were being implemented by craftspeople from the construction industry. A follow up interview with one of the teachers from Åfjord, who still teaches practice based Passive House construction, took place in 2017 and is included in the dataset. This interview looked back on the changes in the building regulations and the activities of the craftspeople between 2012 and 2017.

In the case of ZEB Living Lab eight craftspeople involved in the last phase of the construction in 2015 agreed to be interviewed, a carpenter, an automation engineer (responsible for programming the technical systems), an engineer who specialises in solar technology, the architect and three electricians. The semi-structured interviews took place while we were preparing for a residential experiment in Living Lab. We also had meetings and conversations with several of the engineers involved in designing the lab, and with electrical engineers at campus management responsible for operating the building, (the most pertinent are presented in table 2). Prior to the completion of the house, we visited the building site, saw the craftspeople in action and observed discussions.

\section{TABLE 2}

\begin{tabular}{|c|c|c|c|}
\hline$\#$ & $\begin{array}{l}\text { Informant/ } \\
\text { interviewee }\end{array}$ & $\begin{array}{l}\text { Number } \\
\text { of people }\end{array}$ & $\begin{array}{l}\text { Type } \\
\text { of data }\end{array}$ \\
\hline 1 & Carpenter (Petter) & 1 & One semi-structured interview \\
\hline 2 & $\begin{array}{l}\text { Automation } \\
\text { engineer (Emil) }\end{array}$ & 1 & One semi-structured interview \\
\hline 3 & Solar engineer (Ola) & 1 & $\begin{array}{l}\text { One semi-structured interview } \\
\text { over Skype }\end{array}$ \\
\hline 4 & Architect & 1 & One semi-structured interview \\
\hline 5 & $\begin{array}{l}\text { Two electricians } \\
\text { (Espen \& Ove) and } \\
\text { one HVAC engineer }\end{array}$ & 3 & Focus group interview \\
\hline 6 & $\begin{array}{l}\text { Electricity engi- } \\
\text { neer, campus } \\
\text { management }\end{array}$ & 1 & $\begin{array}{l}\text { One semi-structured interview } \\
\text { over telephone (2016) }\end{array}$ \\
\hline 7 & $\begin{array}{l}\text { Electricity engi- } \\
\text { neer, campus } \\
\text { management }\end{array}$ & 1 & $\begin{array}{l}\text { One semi-structured interview } \\
\text { over telephone (2016) }\end{array}$ \\
\hline 8 & $\begin{array}{l}\text { Carpenters, electri- } \\
\text { city engineers, } \\
\text { building physicist } \\
\text { from NTNU, auto- } \\
\text { mation engineer }\end{array}$ & $3 / 4$ & $\begin{array}{l}4 \text { Site visits Living } \\
\text { Lab - observation }\end{array}$ \\
\hline 9 & $\begin{array}{l}\text { Campus } \\
\text { management }\end{array}$ & 6 & $\begin{array}{l}\text { One meeting - observed } \\
\text { discussion }\end{array}$ \\
\hline 10 & $\begin{array}{l}\text { Carpenters, build- } \\
\text { ing physicist from } \\
\text { NTNU, represen- } \\
\text { tative from window } \\
\text { factory, resident }\end{array}$ & 9 & $\begin{array}{l}\text { Window maintenance } \\
\text { - observed discussion } \\
\text { over one day }\end{array}$ \\
\hline
\end{tabular}

Table 2: Overview of data collection in ZEB Living Lab 


\section{N}

NORDIC JOURNAL

of Science and Technology Studies

The analysis process has been anthropological taking the empirical data as starting point for the analysis. However, following principles of 'abductive reasoning', both field data and existing theory were allowed to influence the researchers in the analysis process (Reichertz 2007 $7^{[r]}$. Therefore, instead of forcing either the theory or the data into a framework, the researchers left space for their own logical reasoning (ibid.). We assessed interview transcripts, notes, reports and papers associated with the two projects and considered the response of craftspeople in terms of the impact the building regulations have on the craftsperson when putting his or her skills into practice. In addition, we have reviewed the building regulations themselves, looking at requirements and changes that they imply. In the following section, the starting point is where and when skill meets building regulations during the construction of the two houses. The analysis emphasises the description by the craftspeople of their experiences with the process and their reflections over the changes implied by the building regulations. This enables an analysis that considers how it has been possible to bend the materials and tasks to the purpose when meeting the technical and functional challenges implied by the building regulations.

\section{Upscaling material use, and existing cultural resources}

The following analysis is based on an interest in the impact of the building regulations on craftspeople working with two different 'super-insulated' construction cases in Norway. We start by presenting the more bottom-up Åford case, and then proceed with the more top-down ZEB Living Lab case.

\section{The bottom-up educational perspective in Åfjord}

The Passive House standard implies new knowledge and potentially a new set of skills. The course in Åfjord took place in 2012-13 before the building regulation including Passive Houses became standard and at a time when the Passive Houses were a new phenomenon in Norway ${ }^{14}$. Teaching staff from Åfjord High School believed that by participating in the course, pupils studying carpentry would end up with a better understanding of the skills associated with building Passive Houses and be better prepared to meet the requirements of the building trade when they left school. However, it was initially unclear whether demands in the new building regulations required a new set of skills, or an adjustment of an existing set of skills. Jan, a teacher from Åfjord explained that learning about Passive House standards and building regulations was not about going through the texts approved by the state, but applying what is required in practice, taking drawings made by an architect and making them a reality through the application of their skill:

When we are building, we work with drawings pre-developed according to the requirements. We don't always need to think about the building regulations. They provide the background. It is similar when we teach. We focus on insulation requirements and $U$-values, but we do this without having the building regulations in front of us. They are not described directly in textbooks either, but the text is based on the building regulations.

Interpretation of the regulations happens through use, by putting them into practice. This requires a set of skills and it requires experience. This was something the pupils were in the process of acquiring. Martin, one of the two pupils interviewed, said that he had never built a house before, and that he did not know why
Passive House had become the new standard. When asked if the house would be a good house to live in, Kristin one of the two pupils interviewed replied:

We are receiving help through the whole training process, so I hope that it will be good. It is the first time that we have built a Passive House, so you have to bear that in mind. It will be very nice, but a bit different with its sloping roof. It will be more modern than a normal house.

With so much that was new and different the pupils could have lost sight of what was general carpentry and what was Passive House construction. This was however not the case for the two pupils that were interviewed. When asked whether he thought he would become a better craftsperson, Martin said that:

There is more material to work with, more learning in sawing and hammering. A bit more has to be re-done, although not as much as we expected. We have to go over things, double-check the quality and so on...

Martin understood the building process in a Passive House terms of thicker walls, which he saw as requiring more materials, and the demand for airtightness. When asked if the house would be a good house to live in Martin said, "I wonder what the air will be like on the inside because the house has to be so airtight."

A Passive House has to be approved before it may be called a Passive House; to achieve this label, airtightness is tested. Leakages in the building envelope affect airtightness, and this required extra care from pupils. Kristin, when responding to the same question on craftspersonship, had a similar focus on airtightness: "We are perhaps becoming more careful? We have to be more careful with the airtightness."

Even small mistakes meant pupils had to go back and re-do work they thought that they were finished with. Jan, the teacher from Åfjord also emphasises the need for care because of demands for airtightness:

14 The Norwegian Passive house became established as its own standard in 2013. See NS 3700 https://www.standard.no/nyheter/nyhetsarkiv/bygg-anlegg-og-eiendom/2013/ ns-3700-kriterier-for-passivhus-og-lavenergihus---boligbygninger/ 


\section{N}

NORDIC JOURNAL

of Science and Technology Studies

We had to be more exact. It made us more aware of quality and finish. The pupils were aware of this, and it had implications for our work (carpentry) in general. There were a number of representatives from the construction industry present during presentations (Passive House course) and they asked critical questions about the standard, this heightened the pupil's awareness of the need to be careful and follow up details.

These critical representatives from the industry were also potential colleagues and employers, and their comments made pupils conscious of expectations regarding their skills after they left school. However, Jan also told us that the focus on airtightness was not new: "There was already competition within the industry, about building as airtight as possible. At least among serious actors."

The building regulations and Passive House standard meant that airtightness was expected in all buildings and being worked on by the whole of the industry, not just by a few "serious" actors. This implies a greater focus on the application of skill and the quality of the resulting buildings. An idea supported by the project manager for a building site in Trondheim, where 300 passive-houses were under construction at the time of the Åford project. Pupils visited the site as part of their course work. The project manager for the site suggested that the precision and care required to achieve the air-tightness associated with Passive Houses has resulted in a greater level of skill and professional pride, and in the building of houses of a much better quality (Woods et al. 2013a: $8^{[[]}$).

In Åford we spoke mostly to pupils and teachers, and learning new things, developing skills is what carpentry studies at high school level in Norway is about. Achieving the required airtightness was an issue everyone agreed was a challenge, but a solvable one. Cost was never the main issue in Åfjord. The building project was about providing pupils with a practice-based course in Passive House building. The local construction industry sponsored the project and using pupils to build helped to lower construction costs (Woods et al. 2013b:13;36[r]). A year and a half later in the context of ZEB Living Lab the response to the same qualities was different.

\section{The top-down perspective of ZEB Living Lab}

ZEB Living Lab represents what is expected to be the next stage in building standards in Norway. Living Lab is a pilot building and a laboratory, and is therefore technically complex, leading to several discussions about how to make it work according to specifications. A zero-emission house built for the Norwegian housing market is not expected to include so many systems or to be as complex. For example, Living Lab has three different heating systems, including a solar collector, a ventilation system with an electric coil capable of heating air up to $40^{\circ} \mathrm{C}$ and a ground source heat pump. Emil, an automation engineer who programmed the technical system in Living Lab, emphasised the complexity of the process and the necessity for teamwork. Emil's programming was at the centre of the network of craftspeople, they depended on him to define where their work was to be done. Thus, the speed of his work affected when the rest of the team could do theirs.

Emil was not used to working on houses or with the level of systemic detail required. He described the process of working on ZEB Living Lab as very complicated, with things often being unclear. Emil and the other craftspeople working in Living Lab developed solutions as they worked: "A lot of things were new and the plan changed over time", and this made the process "very time consuming", taking a lot longer to build than expected. Particularly the electricians depended on Emil's work:

It has happened that I have made a mistake, 'miscalculated', but the electrician often has tips and suggestions about possible solutions. So, then we just have to agree on what.

Emil stated that he was not the only one struggling to solve problems:

I know that that the plumber has been scratching his head. Normally the heat pump and the ventilation system live their own lives. Now they are controlled together. We are testing different methods and trying to get things to work together.

Emil was not alone in thinking that the process of building ZEB Living Lab was new and demanding, the whole group involved made similar comments. The teamwork that resulted from this process suggests a complex process, one that demanded creative solutions from the craftspeople. A carpenter who worked on Living Lab, known here as Petter told us:

Disagree or agree, we are better off talking together to find a solution than disagreeing. It is about agreeing on a solution and along with the architect finding the best solution, one which is favourable and which works when put into practice. That is maybe the biggest challenge.

In other words, skill is important to craftspeople, but communication of that skill and making sure it is used correctly is also important.

New knowledge and skills can arise through the new fields and new players can be expected to be included in the future construction of buildings, for example the programming provided by Emil and solar energy production. Ola was the manager of a small company that supplied and installed the photovoltaic systems. The use of photovoltaics on buildings is not new, but installing it on houses is relatively new in Norway and so is its integration with the different systems installed in Living Lab. The house's complexity meant there was limited space for the equipment needed to run the different systems. Ola told us: 


\section{N}

NORDIC JOURNAL

of Science and Technology Studies

There was a lot of pipes, cables and equipment in that little room (the technical room), basically too much. We were originally supposed to put our inverters in there, but they were placed outside.

The complexity of the systems, the timing between the different team players (there were often delays in the construction of Living Lab) and the space needed for the different systems, caused conflicts between fields. According to Ola, the complexity of the building and lack of communication between team members challenged the ZEB concept:

All the different fields should have talked together. This is a building integrated system, which isn't actually so integrated and which has more layers than is really necessary. So, more materials have been used than necessary, to get it screwed into place. For the strictest ZEB standard, this would have been a negative thing.

ZEB Living Lab is a building where expectations about energy efficiency and sustainability are high. Existing skills and knowledge provide a foundation to deal with new standards and solutions. The new team players, represented here by the automation and solar engineers, found the process of integrating with other crafts challenging. The carpenter spoken to in this project was not threatened by changes taking place in the building industry. However, the carpenter and some of the engineers involved did express concerns about economic viability. Petter, the carpenter told us,

It is an advantage that the building is good for the climate, but I think about the customers and the population regarding prices. It might get too expensive for them. This is my job, so if I build a Plus House or a Passive House it is all the same to me, but perhaps this type of solution is more suitable for large buildings that actually use more energy.

This concern can be translated as a somewhat sceptical or critical perception of the project, and implies a rather cautious estimation about the future importance of this type of building. It may also be associated with the conservatism mentioned in the beginning of this paper, which is partially based on a scepticism to anything that increases construction costs, particularly if the company involved is not earning anything from the increase in costs (Ryghaug and Sørensen, 2009:986[r], Risholt and Berker 2013:1027-28[r]). Pilot projects are about testing new solutions, ones that are not widely used on the market; this may cause an increase in costs. An increase in ZEB Living lab that may have caused Petter's scepticism. Pilot projects may therefore not always result in positive dissemination.

The skills provided by the carpenter in ZEB Living Lab represent existing resource, a background of knowledge about the use of carpentry during the construction of buildings. Petter told us:

It's my job, whether I am building a plus house or a Passive House, it's all the same. The difference is the number of different things and tightness. So, for me it doesn't make a difference what I build.

The skills are the same, and he is still building a house, but as mentioned earlier in the context of the Passive House in Åfjord, there are more materials to deal with and a greater focus on detail. Petter had worked on low-energy houses and Passive Houses, the concept of thicker walls and the focus on air-tightness in ZEB Living Lab were not new:

The assembly is the same, but the volume is perhaps greater. Instead of one packet of insulation we are using two. And then there is a new type of vapour barrier that I have never used before, which also is supposed to equal five centimeters of insulation. It is not much more complicated to build it, but you need more time, especially with this new vapour barrier where all the joints need to be taped.

Building highly insulated houses has become part of the existing knowledge associated with established skills. Petter understood constructing airtight houses as the use of existing skills rather than something extra and it was not a big challenge.

Petter emphasised that "we still need to solve things in a good way, so that they work". Zero emission houses, like ZEB Living lab, also need to be functional offering a meaningful context for social relations. Outside the context of ZEB Living Lab, craftspeople believe that homeowners are not ready for the solutions available. In addition, there is no cost incentive for craftspeople to encourage homeowners to install more energy efficient solutions, because he earns no more from installing these solutions (Risholt and Berker 2013:1027 $\left.7^{[\mathrm{r}}\right)$. In Living Lab, the end-user was not the homeowner, but the project leadership in the ZEB Centre, who had extensive knowledge about the available solutions and was not as dependent on economic considerations as a homeowner would have been. This competent end-user meant that there were tough negotiations between the different parties when choosing and planning solutions. Pilot buildings provide inspiration and examples about how to do things, but in the case of ZEB it also implied higher costs and greater complexity.

The description by the team of electricians working on Living Lab suggests a link between existing and new skills. They worked closely with different kinds of craftspeople and their established knowledge and skills were useful when working with both the previous and new building regulations. Espen gave us an example, when answering our question about whether working on the house had been an interesting learning process: 


\section{N}

NORDIC JOURNAL

of Science and Technology Studies

It is a little bit of both: you get some new knowledge about what the solar engineer does. But what I am doing is laying wires and cables for him. I'm still laying cables, but you do sort of pick up bits of information.

When asked if there was anything new or difficult involved in the construction of ZEB Living Lab, they said several times that there was not much that was.

The main challenge was the amount of equipment that went into the house and the time the house took to complete. In such a complex building, good designs and timing were essential. That the design process now includes new tools producing 3D digital models was looked upon by the team as positive, as long as their knowledge and experience is also included. Ove, one of the electricians provided insight into the process:

\section{Discussion and conclusions}

The Åfjord case and ZEB Living Lab represent two different stages in the building regulations; they also offer insight into the response by two different generations of craftspeople to what the changes introduced by the building regulations imply. In Åford, we met a group of pupils and their teachers. The whole process of building the house was about the learning new skills, both general carpentry skills and Passive House knowledge and skills. The example highlights the social process of skill transfer from experienced craftspeople to the high school pupils, at the same time as it offers an interpretation of the skills rather than rigid transfer (Ingold 2009:92 $2^{[r]}$. The pupils were at the start of their careers in the construction industry and as such not hampered by experience. Craftspeople in ZEB Living Lab were experienced within their fields, challenges were all solvable, but they saw the construction process not just in terms of the application of their skills, but also within a wider context of their experience in the construction industry and when dealing with customers. From this perspective, an increase in costs cannot be solved as easily as a reuse or readjustment of skill and time is money.

In this paper, we have considered the negotiations between the meaning, value and skill when a craftsperson deals with a set of new or forthcoming building regulations. In the context of the Passive House and the zero emission building (ZEB), we saw no sign of a reduction in dedication, due to the demands set by changes in building regulations, nor did we see a reduction in the need for skill when carrying out the construction work. Craftspeople within the construction industry continue to apply their craft and to produce good work (Sennett 2008:20[r). Even when faced with changes in building regulations. The regulations require buildings to be energy efficient, material intensive, airtight, highly technical wooden houses does require craftspeople to review their skills, but the craftspeople in this study do not see themselves as needing new what was traditional before was models and drawings just being seen from the top down. Where they look very good before you notice that they collide massively with other stuff.

With the new 3D drawing tools, it is possible to "run a crash test, they just press a button and 'Bang!', up pops a mark where it collides."

The building process is a continuously shifting perspective based on tradition and innovation (Gell 1998:256[r]). Each new house points the way towards houses that are yet unbuilt. The electricians' insights show how new skills and technical changes are filtered through existing resources in the form of pre-existing skills and knowledge. This allows solutions for sustainable requirements to be developed, but it can also provide barriers, because what is built is often the best possible compromise in the light of all the practical difficulties and constraints that are met (ibid.: 257).

skills. They had reconsidered their skills and found them capable of dealing with the changes, but at the same time, they discovered a need for more care and control when applying those skills. Energy and material efficient buildings allow no room for cutting corners, airtightness is tested and approved and leakages mean redoing things and a potential increase in costs.

Building regulations represent a frame of meaning with which to control the construction industry: the intention is to elicit buildings that use less energy, are more material efficient and capable of dealing with the milder, wetter climate that Norway is increasingly experiencing. This paper shows that requirements are not necessarily difficult when it comes to applying skill. Rather, difficulties arise when new or previously unfamiliar groups of craftspeople have to work together on rather complex technologies not yet tested, and where time, cost and vested interest in creating 'dazzling' demonstration projects frame the construction process. The small actors or individual craftspeople have been in focus, how they deal with the overreaching system of the building regulations and remain future oriented (Gell 1998:25 $G^{[r]}$ ). These small actors although future oriented in how they offer solutions to practice based problems also represented a conservative voice within the construction industry; an industry not known for being receptive to change (Stortingsmelding om bygningspolitikk, 2012 $\left.2^{[r]}\right)$. The two pilots had two different aims; the Åfjord project was practice-based. Craftspeople learnt about the Passive House standard through the building process, the project was based on their needs. ZEB Living Lab, on the other hand, intended mainly to 'dazzle', and craftspeople did not feel fully engaged with the development of a high-tech and potentially expensive building. In ZEB Living Lab, the application and adaptation of craftspeople's skills was not experienced as a major challenge, but rather complications occurred due to a high-tech pilot ambition that required time, coordination and was understood as cost intensive. 


\section{$\$$}

NORDIC JOURNAL

of Science and Technology Studies

Developing pilot buildings in collaboration with the industry is a way to deal with some challenges, real-life examples that show the way, demystifying and presenting impressive craftspersonship. However, the complexity of the ZEB Living Lab appears to be counterproductive: craftspeople remain sceptical to the zero emission reality that it proposes, doubting that such a complex house could actually become a widespread solution for the general public. In addition, the building costs remain a barrier. We therefore conclude that pilot buildings should show the way forward, and at the same time avoid focus on building complexity and costs. The Åford project became a model for other practice-based construction projects for high schools in Central Norway and closing the gap between research, demonstration and practice suggests a way to go (van Bueren and De Jong 2007:554 ${ }^{[\mathrm{rl}}$ ). Hands-on experience based on traditional building skills continues to have value in the construction industry and this can play a role in bridging the gap between conservatism and reinterpretation of crafts.

\section{Acknowledgements}

This paper has been written with support from the Norwegian State Housing Bank and the Research Centre on Zero Emission Buildings (ZEB). The authors gratefully acknowledge the support from the Research Council of Norway, BNL - Federation of construction industries, Brødrene Dahl, ByBo, DiBK - Norwegian Building Authority, Caverion Norge AS, DuPont, Entra, Forsvarsbygg, Glava, Husbanken, Isola, Multiconsult, NorDan, Norsk Teknologi, Protan, SAPA Building Systems, Skanska, Snøhetta, Statsbygg, SørTrøndelag Fylkeskommune, and Weber. We are grateful for the constructive feedback from the two anonymous reviewers. Their advice helped us to develop and improve the paper.

\section{References}

Andresen, I., Hegli., T. 2016 The Integrated Design Process. In Zero Emission Buildings. (Eds) Hestnes, A.G., Eik-Nes, N.L. Fagbokforlaget. Bergen. ISBN: 978-82-450-2055-7

Andresen, I., 2017 Pilot Buildings: Lessons Learned. In ZEB Final Report 2009-2017. ISBN 978-82-690808-1-0 http://www.zeb. no/index.php/en/final-report

Berardi, U. 2013 Clarifying the new interpretations of the concept of sustainable building. Sustainable Cities and Society. Volume 8, October 2013, Pages 72-78

Buchli, V. 2013 An Anthropology of Architecture. Bloomsbury. London.

European Norm (EN) 15643-1. 2010. Sustainability of construction works - Sustainability assessment of buildings - Part 1: General framework.

Direktoratet for byggkvalitet 2011 (Revised 2016) Byggteknisk forskrift (TEK 10). HO-2/2O11

Gell, A., 1998 Art and Agency: An Anthropological Theory. Clarendon Press. Oxford.

Georges, L., Alonso, M. J., Woods, R., Wen, K., Håheim, F., Liu, P., Thalfeldt, M., (2017) Evaluation of simplified space-heating hydronic distribution systems for Norwegian passive houses. Forthcoming. SINTEF Akademisk forlag.

Goia, F., Finocchiaro, L., Gustavsen, A. 2015 The Living Laboratory at the Norwegian University of Science and Technology: A Zero Emission House for Engineering and Social Science Experiments. Passivhus Norden: Sustainable Cities and Buildings. Copenhagen, 20-21 August 2015.

Gunn, W. 2006. Learning within the workplaces of artists, anthropologists and architects: Making stories for drawings and writings. In Grasseni, C (ed), Skilled Vision: Between Apprenticeship and Standards. Berghahn Books: Oxford, pp. 106-125.

Gustavsen, A. 2017 Showing the Way. In ZEB Final Report 20092017. ISBN 978-82-690808-1-0 http://www.zeb.no/index.php/ en/final-report

Hargreaves, T., Wilson, C., \& Hauxwell-Baldwin, R. 2017 Learning to live in a smart home. Building Research \& Information, 1-13.

Henare, A., Holbraad, M., Wastell, S. 2007 Introduction: thinking through things. In Thinking Through Things: Theorising artefacts ethnographically. Routledge. London.

Ingold, T. 2009 The textility of making. Cambridge Journal of Economics, Volume 34, Issue 1, 1 January 2010, Pages 91-102, https://doi.org/10.1093/cje/bepo42

Korsnes, M. 2018 'Householders as co-producers: lessons learned from Trondheim's Living Lab', ECEEE 2017 Summer Study on energy efficiency conference proceedings, http://proceedings. eceee.org/vispanel.php?event =7 (accessed 19 July 2017).

Korsnes, M., Berker, T. and Woods, R., 2017 "Domestication, acceptance and zero emission ambitions: Insights from a mixed method, experimental research design in a Norwegian Living Lab", Energy Research and Social Science. Volume 39, May 2018, Pages 226-233, https://doi.org/10.1016/j.erss.2017.11.004

Miller, D., ed. 1983 Things ain't what they used to be. Royal Anthropology Institute. News. 59:5-16

Ministry of local government and regional development, 2012 Good buildings for a better society

Parag, Y., Janda, K. B. 2014 More than a Filler: Middle Actors and Socio-technical Change in the Energy System from the "MiddleOut". Energy Research and Social Science 3 (2014) 102-112.

Pink, S. 2009 Doing Sensory Ethnography. Sage publications Ltd. London.

Owens, A., Mitchell, G., Gouldson, A. 2014 Unseen Influence - The Role of Low Carbon Retrofit Advisors in the Adoption and Use of Domestic Energy Technology. Energy Policy 73 (2014) 169-179.

Reichertz, J., 2007. Abduction: The logic of discovery in Grounded Theory. In A. Bryant \& K. Charmaz, eds. The Sage Handbook of Grounded Theory. Sage, pp. 214-228.

Risholt, B., Berker, T. 2013 Success for energy efficient renovation of dwellings - Learning from private homeowners. Energy Policy. vol. 61 .

Risholt, B. 2016 The Building Envelope: It is not Only about Insulation. In Zero Emission Buildings. (Eds) Hestnes, A.G., Eik-Nes, N.L. 
Fagbokforlaget. Bergen. ISBN: 978-82-450-2055-7

Ryghaug, M., Sørensen, K.H., 2009 How energy efficiency fails in the buildingindustry. Energy Policy 37 (2009) 984-991.

Sennett, R. 2008 The Craftsman. Penguin Books. London.

Standard Norge (2010) NS 3700 Criteria for passive houses and low energy houses and residential buildings.

Stender, M. 2017 Towards an Architectural Anthropology - What Architects can Learn from Anthropology and vice versa, Architectural Theory Review, 21:1, 27-43, http://doi.org/10.1080/13264 $\underline{826.2016 .1256333}$

Stortingsmelding om bygningspolitikk, 2012, Ministry of the Environment, Norway

van Teijlingen E., Hundley, V., 2001 The importance of pilot studies. Sociology at Surrey University of Surrey. Social researchUPDATE. ISSUE 35. ISSN: 1360-7898.

Van Bueren, E., De Jong, J. 2007 Establishing sustainability: policy successes and failures. Building Research and Information, 35:5, 543-556, http://doi.org/0.1080/09613210701203874

Wade, F., Hitchings, R., Shipworth, M. (2016) Understanding the Missing Middlemen of Domestic Heating: Installers as a Community of Professional Practice in the United Kingdom. Energy Research and Social Science 19 (2016) 39-47.

Woods, R., Kjølle H. K., Gullbrekken, L., 2013a Sustainable Low Cost Housing for the Socially Disadvantaged: The Vassneset Example. 7th Nordic Conference on Construction Economics and Organisation 2013. Trondheim Akademika forlag ISBN 978-82-321-0273-0.

Woods, R., Kjølle, K. H., Gullbrekken, L., 2013b Rimelige boliger for vanskeligstilte, fase 3. SINTEF Byggforsk. SINTEF akademisk forlag ISSN 1894-2466.

EU Roadmap 2011, http://eur-lex.europa.eu/legalcontent/EN/TXT/ PDF/?uri=CELEX:52011DC0 $571 \&$ from $=E N$ 